\title{
EVAPORITE KARST AND HYDROGEOLOGY OF THE CASTILE FORMATION: CULBERSON COUNTY, TEXAS AND EDDY COUNTY, NEW MEXICO
}

\author{
Kevin W. Stafford \\ Department of Geology, Stephen F. Austin State University, P.O. Box 13011, SFA Station, Nacogdoches, Texas, \\ 75962-3011,staffordk@sfasu.edu
}

\begin{abstract}
Karst development in Permian Castile evaporites has resulted in complex speleogenetic evolution with multiple phases of diagenetic overprinting. More than 10,000 surficial features, primarily sinkholes, occur throughout Culberson County, Texas, and Eddy County, New Mexico, based on GIS-analyses where laminated Castile sulfates crop out. Cave development is largely the result of hypogene processes, where ascending fluids from the underlying Bell Canyon Formation migrate near vertically through the Castile Formation, creating caves up to 100 meters deep and over 500 meters long, which have been breached through a combination of collapse and surface denudation. Numerous small and laterally limited epigene features occur throughout the region, as well as the anomalously large Parks Ranch Cave System with more than 6.5 kilometers of cave development and multiple large, incised, sinkhole entrances. Hypogene caves exhibit varying degrees of epigenic overprinting as a result of surficial breaching.
\end{abstract}

Water resources in the Castile Formation are directly related to karst development with extremely heterogeneous flow networks. Most springs in the region discharge sulfate-rich waters, contain high levels of hydrogen sulfide, and support sulfate-reducing bacterial colonies. Isolated stream passages in northern Culberson County provide locally significant water resources that do not exhibit elevated hydrogen sulfide concentrations. Local water tables vary greatly over the region and few caves access base-level conditions. Upward migration of hydrocarbons complicates regional hydrology and diagenesis, resulting in extensive evaporite calcitization, which greatly modifies both fluid / rock interaction and permeability structures.

\section{Introduction}

The arid southwestern United States hosts unique evaporite-karst development, including extensive caves and rapidly evolving landscapes, all of which are coupled to a complex and poorly understood hydrogeologic system. The Gypsum Plain is a large expanse of Permian-age evaporites that crop out in eastern New Mexico and far west Texas, with Castile strata outcrops limited to Eddy County, New Mexico, and Culberson County, Texas, along the western edge of the Delaware Basin (Figure 1). The region occurs within the northern portion of the Chihuahuan Desert with annual temperatures averaging $17.3^{\circ} \mathrm{C}$ and an average low and high of $25.2{ }^{\circ} \mathrm{C}$ and $9.2{ }^{\circ} \mathrm{C}$, respectively (Sares, 1984). Annual precipitation averages $267 \mathrm{~mm}$, with greatest concentration occurring as high-intensity, short-duration events that promote rapid runoff associated with latesummer monsoonal storms.

Cave and karst development in far west Texas and southeastern New Mexico is extensive and widespread; however, most people envision the famous carbonate caves of the Guadalupe Mountains (e.g. Carlsbad Cavern, Lechuguilla Cave) when they think of this region, which have developed in Guadalupian reef(Capitan Formation) and near-backreef facies (Yates and Tansil formations) (Figure 2) (Hose and Pisarowicz, 2000). While often overlooked and generally less studied, evaporite karst in the region is more extensive and widespread. In the contemporaneous Guadalupian backreef facies, interbedded gypsum, carbonate, and clastic strata host numerous well-developed cave systems in the Artesia Group (Stafford and Nance, 2009). Post Guadalupian deposition, Ochoan basin-filling evaporites host extensive karst development in the Castile Formation, while strata overlying (Salado and Rustler formations) the Permian reef and basin-filling deposits exhibit similar karst development (Stafford and Nance, 2009).

Most research on evaporite karst associated with Permian deposition in the region has received little study, including geology (e.g. Forbes and Nance, 1997; Nance, 


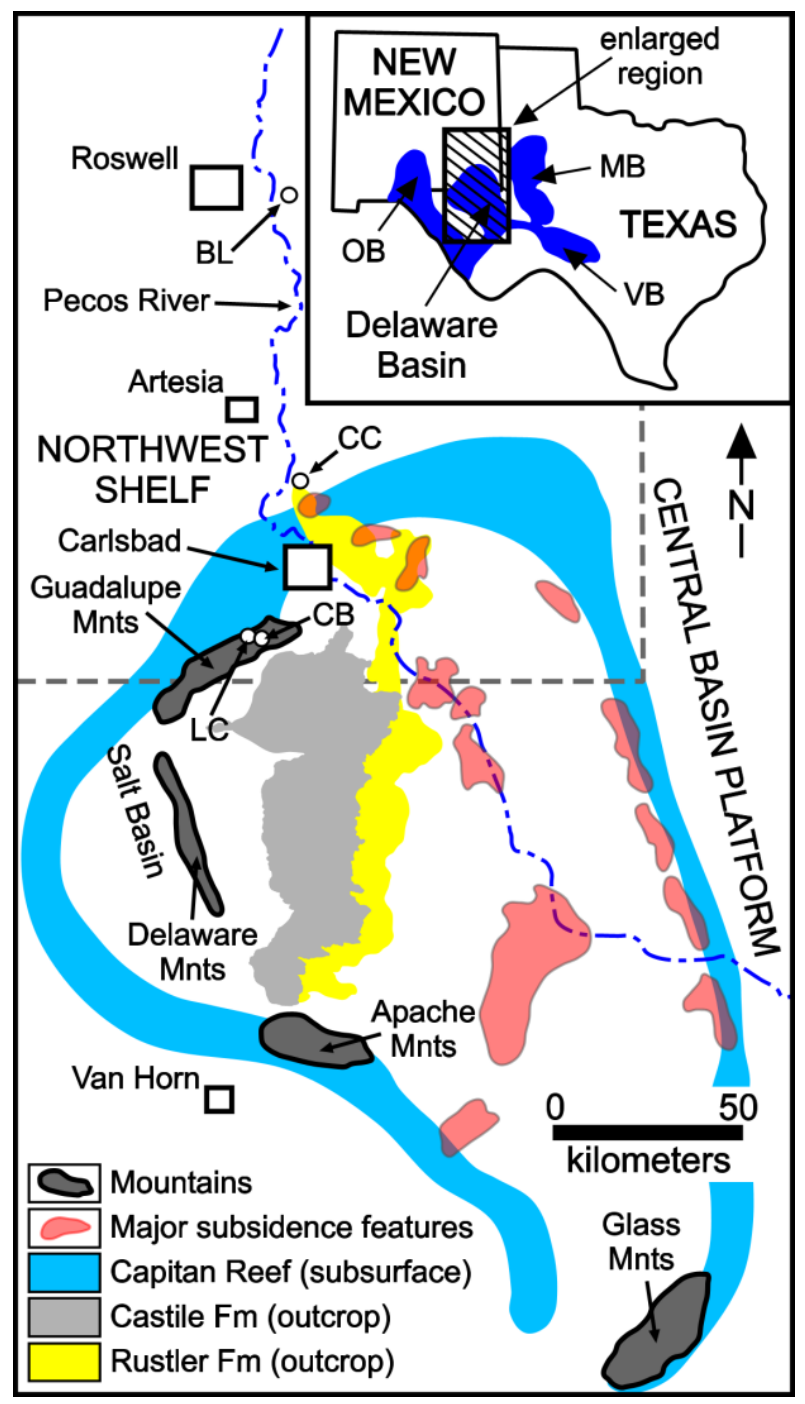

Figure 1. Castile Formation outcrop area showing relationship to major depositional features of the Delaware Basin and geomorphic features. Small inset shows relationship of Delaware Basin to the Orogrande Basin (OB), Val Verde Basin (VB) and Midland Basin (MB) (from Stafford et al., 2008c).

1993) and hydrology (e.g. Land 2006; Sares, 1984), with limited reporting associated with karst inventories conducted in conjunction with the Gypsum Karst Project (GYPKAP) of the National Speleological Society (e.g. Eaton, 1987; Belski, 1992; Lee, 1996). In the last decade, the Castile has been studied more significantly in an attempt to characterize its speleogenetic and diagenetic evolution of basin-filling evaporites (e.g. Stafford et al., 2008a, 2008b). Castile evaporites host a complex history that includes phases of hypogene and epigene cave development, high rates of landscape denudation, extensive evaporite calcitization, and a highly heterogeneous karst-aquifer system, thus creating a complex and evolving hydrogeologic system.

\section{Study Area}

The Castile Formation crops out over approximately $1800 \mathrm{~km}^{2}$ in Eddy County, New Mexico, and Culberson County, Texas, extending from the Guadalupe Mountains in the north to the Apache Mountains in the south (Figure 1). The western portion of the Castile Formation exposure on the Gypsum Plain is formed by erosional truncation associated with the uplifted Delaware Mountains. To the east, the Castile Formation dips into the subsurface beneath younger strata where it reaches a maximum thickness of 480 meters (Kelley, 1971). Intrastratal speleogenesis and diagenetic alterations occur throughout the eastern portion of the Delaware Basin where Castile evaporites are exposed at the land surface (Stafford et al., 2008a). Permeable siliciclastics of the Bell Canyon and Cherry Canyon formations underlie the Castile Formation throughout the Delaware Basin; the carbonate reef facies of the Capitan Formation laterally limited Castile Formation basin-filling deposits (Figure 2) (Lee and Williams, 2000).

The Castile Formation was deposited in the Ochoan, subsequent to the Guadalupian deposition of the Capitan Reef, which is now exposed at the surface in the Guadalupe and Apache Mountains. Castile evaporites represent deep-water, restricted marine deposits which formed within the stratified, brine-filled Delaware Basin at the end of the Permian (Kirkland and Anderson, 1970; Kendall and Harwood, 1989). Castile strata consist of laminated calcite / gypsum (anhydrite) with interbedded halite. Sulfates are hydrated to gypsum near the surface and throughout the Gypsum Plain, but remain dehydrated in the deeper subsurface. Similarly, halite interbeds are

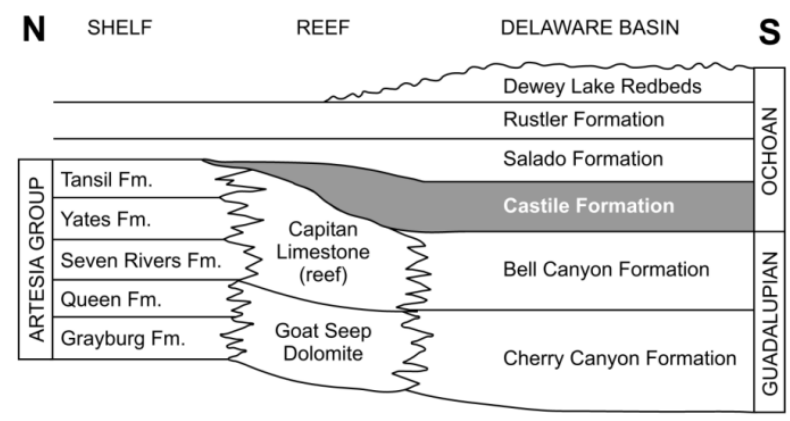

Figure 2. Simplified stratigraphic section of Permian strata in the Delaware Basin region (adapted from Scholle et al., 2004). 
limited to more deeply buried portions of the Castile Formation where they have not been removed by intrastratal dissolution (Kelley, 1971). Calcite laminae were deposited during wetter / less-saline periods, while sulfate / halite laminae were deposited during dryer / more-saline periods. Commonly, original laminated fabrics have been diagenetically altered since deposition, creating irregularly laminated, massive, nodular, and selenitic textures (Hill, 1996).

Throughout the Castile Formation, evaporite calcitization is common and widespread. Stafford et al. (2008c) documented more than one thousand regions of calcitized evaporites exposed at the surface across the Gypsum Plain (Figure 3). These regions were subdivided into calcitization associated with vertical breccia pipes and calcitization associated with intrastratal dissolution of beds that created sheet-like horizons of brecciation. Kirkland and Evans (1976) attributed these calcitized evaporites to bacterial sulfate reduction; however, isotope analyses by Stafford et al. (2008c) showed that isotopic fractionation was insufficient to unequivocally differentiate the calcitization as being the result of bacterial sulfate reduction or thermal sulfate reduction. These extensive calcitized evaporites have formed along high-permeability zones where ascending hydrocarbon gases delivered from the underlying Bell Canyon and Cherry Canyon formations have migrated through Castile strata (Stafford et al, 2008c). Associated with most of the calcitized evaporites, intrastratal dissolution and recrystallization of microcrystalline sulfate into macrocrystalline sulfate (selenite) is common, as well as native sulfur, which is limited due to high rates of oxidation in near surface calcitized zones.

\section{Surficial-Karst Development}

Surficial-karst development where the Castile Formation crops out is widespread and diverse, ranging from large sinkholes to small karren developed on exposed bedrock (Stafford et al., 2008b). The Castile Formation has been heavily modified by surficial processes, with gypsic soil developed across the majority of the outcrop area (Figure 3 ); however, approximately eight percent $\left(\sim 140 \mathrm{~km}^{2}\right)$ of the surface area is composed of exposed bedrock and less than one percent is calcitized evaporites. Alluvium associated with Quaternary gravels commonly occurs along incised drainages, while residual outcrops of the Rustler Formation occur as patchy remnants across the eastern and southern portion of the Gypsum Plain.

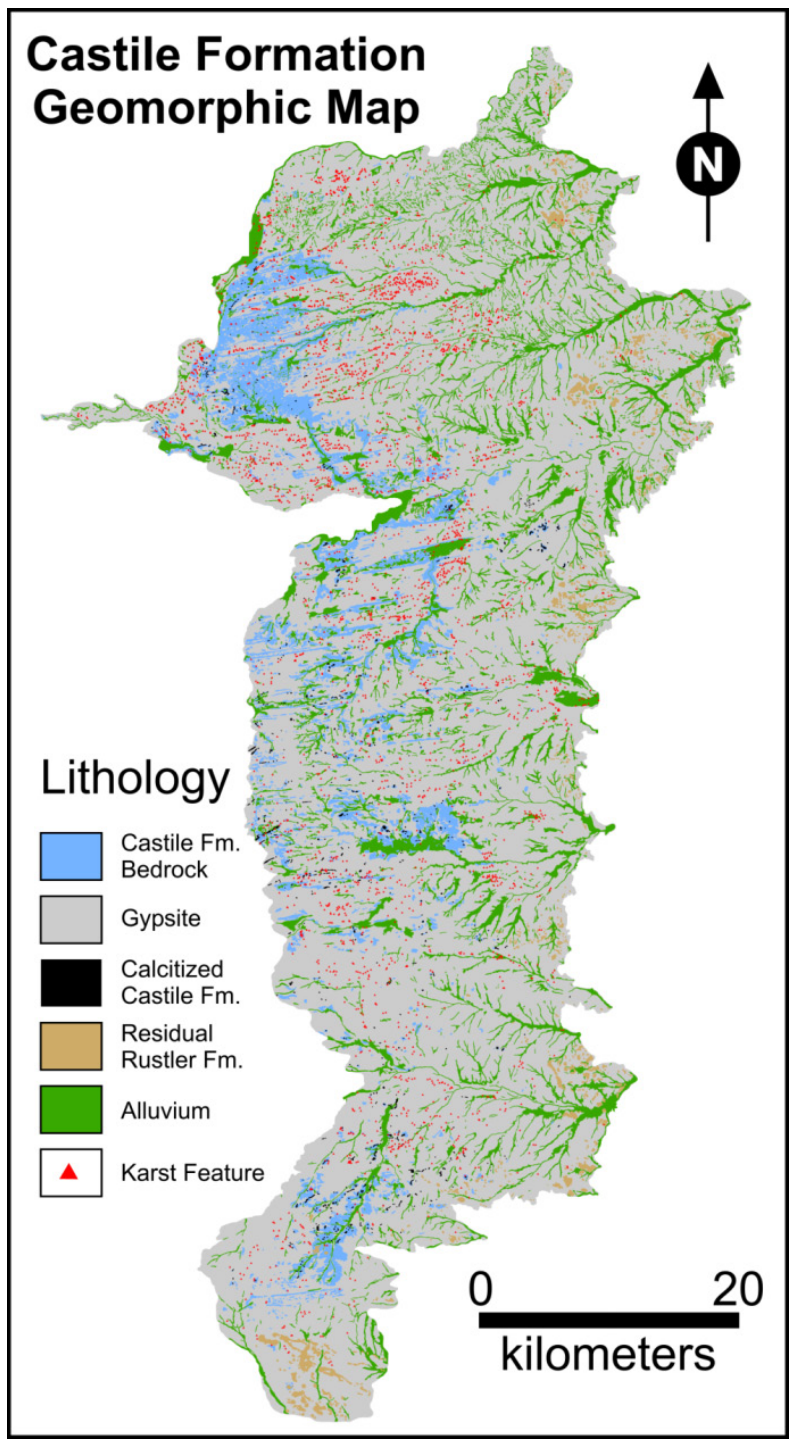

Figure 3. Castile Formation outcrop area geomorphic map, delineating zones of exposed bedrock, gypsite, calcitized evaporites, and karst features.

Solutional karren are well-developed on exposed bedrock, with typical varieties associated with the slope of the rock surface they are developed upon (Stafford et al., 2008b). Deeply incised rillenkarren form long solutional flutes on dipping rock surfaces, with the depth and length of rillenkarren increasing proportionally from moderately dipping surfaces to near vertical surfaces. Centimeter-scale spitzkarrren commonly occur at the apexes of dipping rock surfaces and converge through dendritic channels into rillenkarren. Kamenitzas form on near-horizontal rock surfaces, producing up to decimeterdeep solution pans that are floored with millimeter-thick algal crusts that hydrate during monsoonal storms. In addition to the normal karren forms, tumuli commonly 
occur throughout the Gypsum Plain, where secondary gypsum recrystallization has been laterally confined, resulting in a buckling of the local land surface over regions up to several meters. In regions where karren are less pronounced, cm-thick gypsic crusts develop on bedrock as a result of dissolution and reprecipitation of gypsum at the land surface (Stafford et al., 2008b).

Stafford et al. (2008a) identified 3,237 closed depressions across the Castile outcrop area using GIS analyses that coupled ten-meter digital elevation models with digital orthophoto quad analyses (Figure 4). However, Stafford et al. (2008a) predict that more than 10,000 individual closed depressions exist across the study area based on physical field mapping of fifty, one-square kilometer sites. From this study, sinkholes were classified based on length to width ratios, and it was determined that at least $55 \%$ of the closed depressions were collapse structures while the remaining $45 \%$ were a mix of purely incised arroyos and heavily modified collapse structures (Stafford et al., 2008a). Therefore, the majority of the sinkholes are the result of upward-stoping processes where surface denudation has enabled collapse features to breach the land surface and form surficial expressions of subsurface voids that may not have been originally coupled to surficial, meteoric processes.

The widespread occurrence of collapse sinks and well-developed incised, solutional sinks is directly coupled with the evolution of the Gypsum Plain geomorphology. Shaw et al. (2011) conducted a twoyear investigation of surface denudation across the region utilizing standard gypsum tablets. Their data show that surface denudation rates up to $60 \mathrm{~cm} / \mathrm{kyr}$ occur within the Gypsum Plain (Figure 5); however, the majority of the region exhibits rates that average 30 $\mathrm{cm} / \mathrm{kyr}$, resulting in a high rate of landscape evolution. Most denudation occurs during the late summer /early fall monsoonal season, with rates generally increasing northward away from the Apache Mountains to the Guadalupe Mountains and Pecos River Valley, at the southern and northern margins of the outcrop area, respectively (Shaw et al., 2011). When compared with the distribution of karst development assessed through sinkhole delineation (Figure 4), a similar trend is observed; however, sinkhole distribution is highly localized and occurs more frequently towards the western portion of the Castile outcrop area where total Castile thickness is reduced on the updip side of strata.

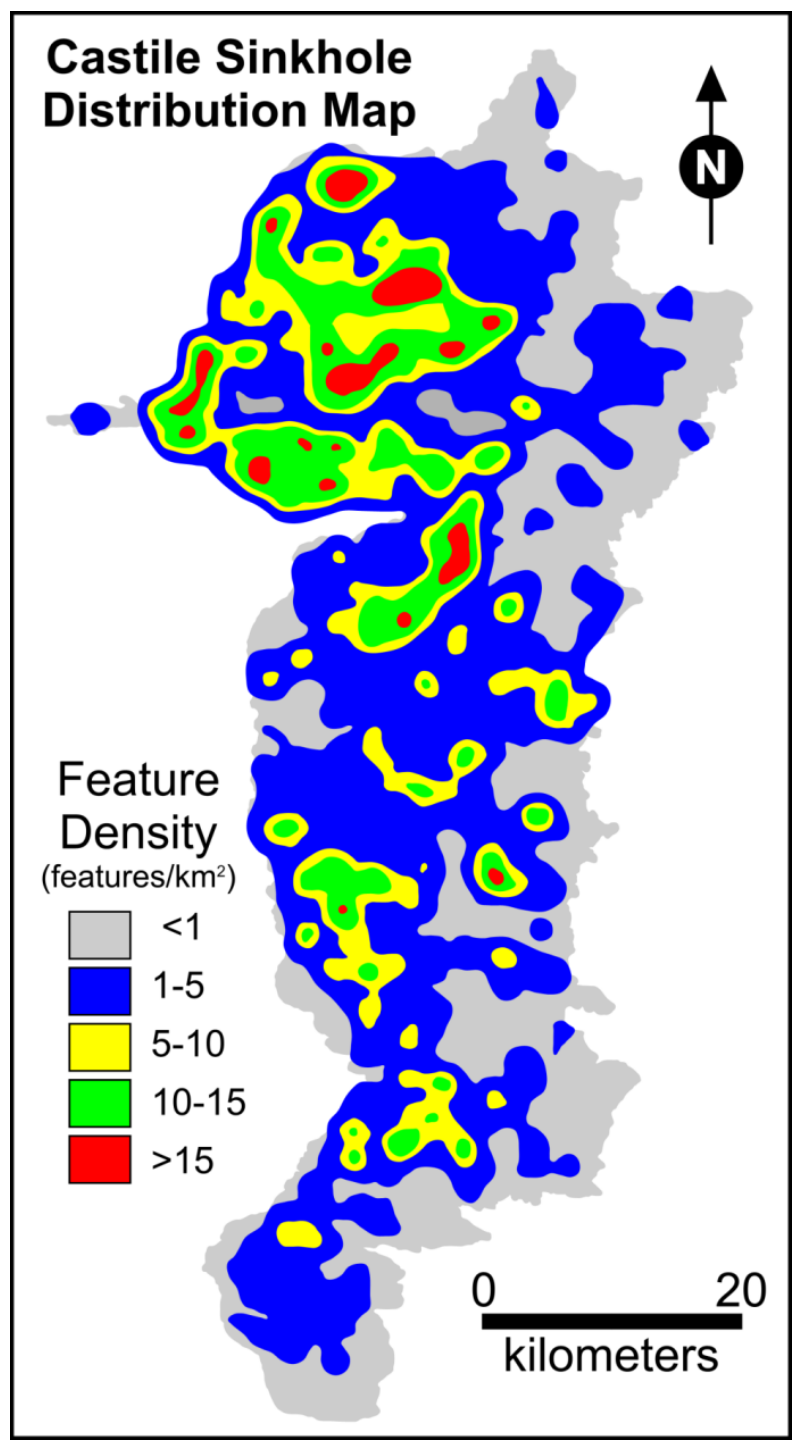

Figure 4. Distribution of closed depressions across the Castile outcrop area derived from GIS analyses (modified from Stafford et al., 2008b).

\section{Subsurface Karst Development}

Cave development in the Castile Formation is diverse and widespread, but not uniform. The spatial distribution of caves mimics that of sink development delineated through GIS analyses (Figure 4), with clusters of intense cave development scattered amongst regions of poor cave development. Caves exhibit varying degrees of structural control, with many features being purely developed along fracture planes, while others show no distinct correlation to structural deformation (Stafford et al., 2008b). Cavernous porosity includes hypogene caves and intrastratal breccias, epigene caves, and hybrids that have resulted from epigenic overprinting of hypogene systems (Figure 6). 


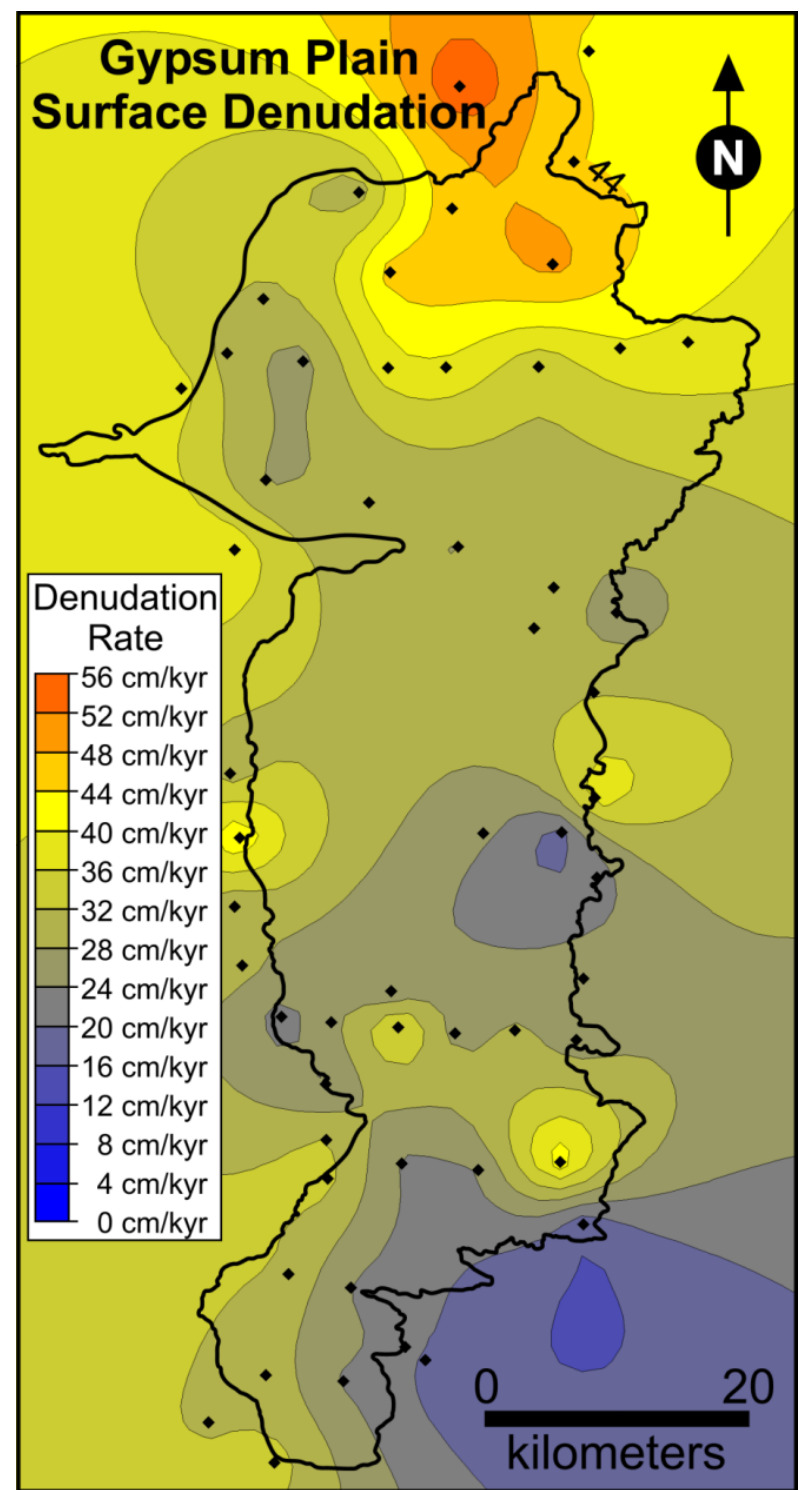

Figure 5. Average surface denudation for the Castile outcrop area based on standard tablet studies (modified from Shaw et al., 2017).

Most caves within the Castile outcrop area are small and laterally limited epigene features (Figures 6A \& $6 \mathrm{~B})$, having formed as either local groundwater recharge features or shallow bypass features proximal to incised arroyos. Epigene caves exhibit scalloped walls, are developed along fracture planes, and can be associated with solutional sinkholes that cover several hectares and entrenched tens of meters. Small scallops on floors, ceilings, and walls indicate that high-velocity fluids routinely pass through these features, likely associated with extensive runoff during monsoonal storm events (Stafford et al., 2008b). Epigene cave apertures rapidly decrease away from entrance areas, generally becoming humanly impassable within a few tens of meters as a result of the rapid solution kinetics associated with calcium sulfate (Klimchouk, 2000). Zombie Cave (Figure 6A) and Dead East Cave (Figure 6B) are the largest purely epigene caves that have been documented within the Castile Formation, with survey lengths of 43 meters and 41 meters, respectively. Although exceptionally large for epigene caves in the Castile Formation, they exhibit typical characteristics, including: 1) narrow apertures developed along dominant fractures; 2) laterally limited, shallow features; and 3) solutional enlargement of secondary fractures proximal to the main conduit development. Most epigene features are developed in laminated, massive, and nodular facies; however, they occasionally develop in tabular (selenite) gypsum along crystal planes and in gypsite soils along zones of permeability contrast.

Hypogene-karst development is associated with extensive and deep cave systems within the Castile Formation, including complex, multi-storey cave systems and isolated solutional chambers (Stafford et al., 2008b). Hypogene caves exhibit classic morphometric features, including risers, cupolas, wallchannels, and ceiling channels, often connected in series that show the complete suite of morphological features created by ascending fluid flow in a mixed convection system (Klimchouk, 2007). Unlike epigene caves, hypogene features do not show rapid decreases in aperture width but instead exhibit zones of increasing pore volume beneath permeability boundary horizons. While hypogene caves do still exhibit passage correlation with fracture planes, they do not show speleogenetic dominance along preferential planes, but instead exhibit dissolution patterns indicative of noncompetitive flow (Stafford et al., 2008b). Dead Bunny Hole (Figure 6C) is developed along a combination of anticlinal structures and fracture planes with complex interconnected passages at multiple levels, while Bee Line Cave (Figure 6E) is largely a single solutional dome room in an ascending series of cupolas that have been overprinted by meteoric processes. Crystal Cave (Figure 6G), the deepest cave in the study area at 93 meters, is effectively a single ascending cupola series with interconnected ceiling and wall channels, in which the lowest portions of the cave descend below the current water table and are developed in selenite. Other hypogene caves in the study area (e.g. Black Dog Cave) exhibit inverse dendritic patterns where multiple 


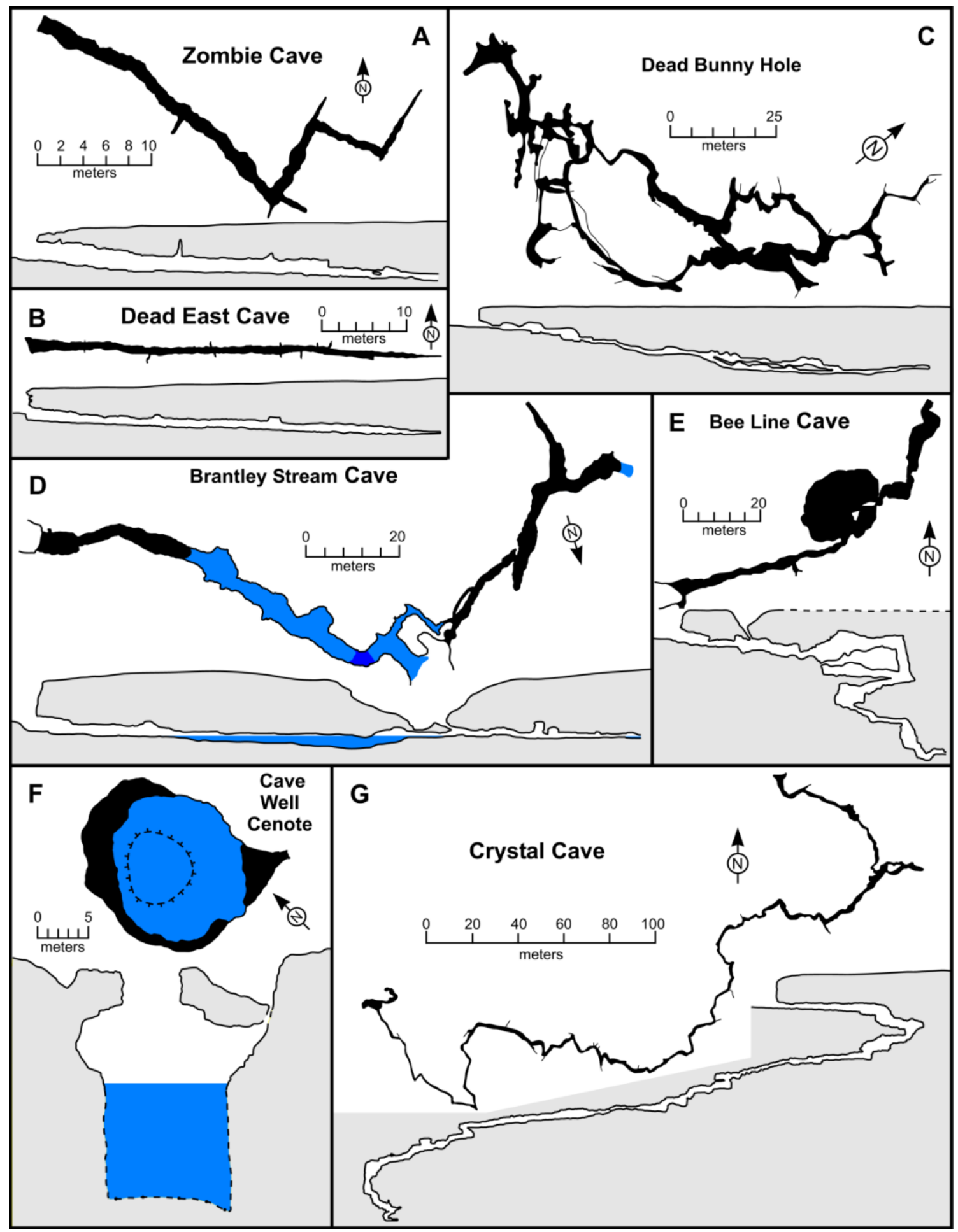

Figure 6. Simplified plan and profile maps of Castile Formation caves, including epigene caves $(A, B)$, hypogene caves $(C, E, G)$, stream caves $(D)$, collapse structures that breach the water table $(F)$ and the deepest cave in the study are which intersects the water table (G). 
ascending fluid paths converge upwards through the subsurface; however, these patterns are not common in the study area.

While hypogene caves are the largest features in the study area, they are not the dominant cave type documented (Stafford et al., 2008b). This is likely a sampling bias because of the nature by which these caves form from ascending, transverse fluid flow. However, many of the hypogene features exhibit strong correlation with regions of evaporite calcitization and diagenetic recrystallization of original gypsum fabrics into tabular fabrics (Stafford et al., 2008c). Therefore, it is logical to assume that the higher-permeability zones created by hypogene karst development and evaporite calcitization were utilized by both ascending waters and hydrocarbons from the underlying Bell Canyon and Cherry Canyon Formations (Figure 7).The largest individual cave currently documented in the Castile Formation is Parks Ranch Cave with over 6.5 kilometers of surveyed passage (Figure 8). This anomaly does not fit the traditional models for either hypogene or epigene karst and likely represents a hybridization of the two genetic forms. Multiple, wellincised solutional sinkholes contribute meteoric runoff to the system which primarily discharges to Chosa Draw, a locally incised valley. Most passages exhibit well-developed scallops and generally the passages form a dendritic pattern; however, upper-level regions exist that are effectively scallop free and contain minor cupolas and poorly developed ceiling / wall channels (Stafford et al, 2008b). The current discharge point in Chosa Draw is a bisected cave passage and continues as a stagnant water-filled conduit on the opposite side of the incised valley, indicating that this spring location is the result of downward cutting of the incised valley and conduit breaching. Parks Ranch Cave appears to contain minor hypogene components that have been connected and heavily overprinted by epigene processes, forming a complex, hydrologically active system.

\section{Water Resources}

Water resources in the Castile outcrop area are scarce and limited to occasional springs, seeps, and caves that breech conduits. Most springs and seeps in the study area exhibit high total dissolved solids, primarily sulfate, as a result of the rapid saturation of waters passing through gypsum facies (Stafford et al., 2008b). However, some springs have low enough total dissolved solids to support diverse ecological systems, including several species of arthropods and healthy, riparian zones at discharge points. All of these features, both sulfaterich and relatively fresh water resources, are utilized by local flora and fauna and are heavily relied upon by local ranchers for livestock.

Many of the springs provide perennial discharge and degas significant quantities of hydrogen sulfide; these springs host large colonies of white filamentous bacteria that are most likely sulfate-reducing forms. These features are likely associated with ascending fluids containing elevated hydrocarbons that provide source material for current evaporite calcitization in the subsurface and represent upward leakage of active hypogene processes to the land surface (Stafford et al., 2008b). China Mine,

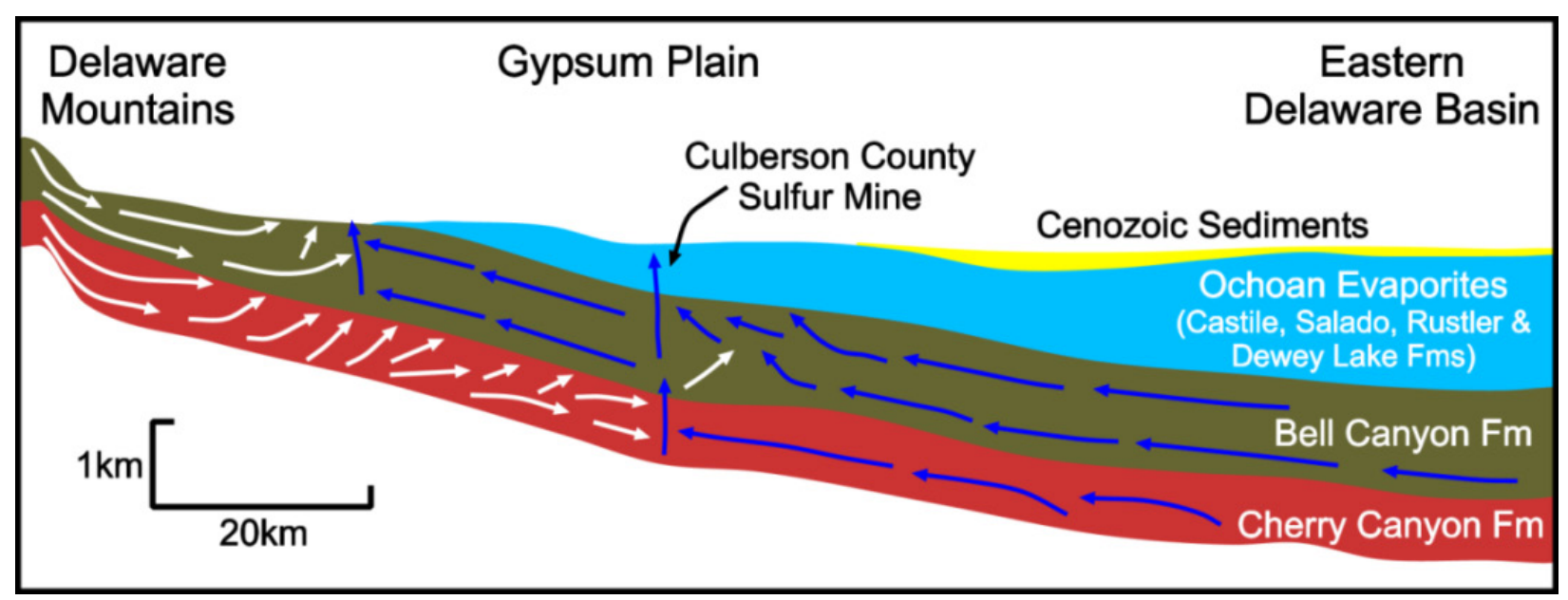

Figure 7. Simplified paleohydrology diagram associated with evaporite calcitization and upward migration of hypogene fluids (adapted from Lee and Williams, 2000). White arrows show migration paths of meteoric waters; blue areas show migration paths of upward migrating, hydrocarbon-rich fluids. 


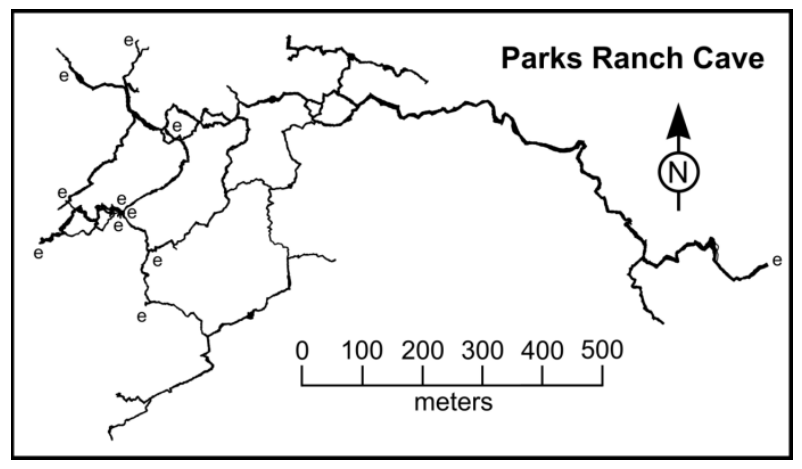

Figure 8. Simplified plan view map of Parks Ranch Cave with entrances labeled ("e"). Note that the easternmost entrance was formed by conduit truncation as Chosa Draw entrenched, while the western entrances are associated with sinkholes (from Stafford et al., 2008a).

an early $20^{\text {th }}$ century sulfur mine in northern Culberson County, currently degasses significant amounts of hydrogen sulfide and shows evaporite calcitization and secondary sulfur deposition but does not exhibit spring discharge (Stafford et al., 2008c); however, it is likely that it is a nonaqueous version of the smaller hydrogen sulfide springs. Similarly, Cave Well Cenote is a collapse structure approximately 15 meters in diameter that drops approximately 10 meters to water which forms a lake 15 to 20 meters deep (Figure 6F). The feature degasses extensive hydrogen sulfide and filamentous bacteria occur throughout the lake. While this feature does not discharge to the surface as a spring, it does provide a window into the local water table, while a nearby water well descends over 50 meters to the local water table.

Several caves in the area are vadose conduits, where relatively unsaturated waters flow through the shallow subsurface. Brantley Stream Cave (Figure 6D) contains over 100 meters of cave passage with an active stream that sumps in regions and discharges to the Delaware River, a perennial stream in northern Culberson County. Similarly, a series of collapse sinkholes intersect a separate conduit system in Sinkhole Flat approximately 20 kilometers southeast of Brantley Stream Cave on the opposite side of the Delaware River. These collapse sinks provide windows into a relatively freshwater conduit system approximately 10 meters beneath the land surface with no obvious surface connections; however, the stream exhibits low total dissolved solids. In the southern portion of the study area, Crystal Cave descends to a depth of 93 meters where the passage becomes sumped (Figure 6G), but does not exhibit indications of high hydrogen sulfide and is relatively fresh. These features along with other isolated caves across the study area provide windows into the current hydrologic system, which are distinctively different than those water resources with active filamentous microbial communities.

Water resources across the Gypsum Plain provide a glimpse into the extremely heterogeneous hydrogeologic system. Fluid chemistry varies rapidly over distances of several kilometers, with water tables that appear to fluctuate extensively across the region. The hydrogeologic system couples components of shallow meteoric flow driven by gravity with ascending fluids that often exhibit a minor thermal component, high total dissolved solids, and host complex bacterial colonies. The complexity of the hydrologic system does not fit simple models for groundwater flow. More research is needed to delineate fluid flow paths across the region, which will need to couple mixed fluid flow components with aquifer compartmentalization.

\section{Conclusions}

The Castile Formation crops out in the western Delaware Basin in Eddy County, New Mexico, and Culberson County, Texas, and hosts extensive karst development. Surface denudation is rapidly modifying the landscape at rates averaging $30 \mathrm{~cm} / \mathrm{kyr}$, which has resulted in the surficial breaching of numerous caves throughout the region. More than ten thousand individual sinkholes have been predicted for the region based on GIS analyses, with over three thousand documented. Sinkholes provide windows into the complex speleogenetic evolution of the region, where hypogene caves form deep and complex systems that are being actively overprinted by epigene processes. Associated diagenetic alteration of the Castile sulfates has produced widespread regions of evaporite calcitization in association with ascending hydrocarbons from underlying clastic strata. The Castile Formation records the evolving hydrogeologic history of the Delaware Basin as multiple phases of hypogene and epigene fluids have modified the strata, creating a system that is continuing to be overprinted by current and active processes.

Initial Castile Formation studies indicate a complex hydrogeologic system that couples ascending transverse flow with descending meteoric waters. Mixing fluid chemistries have resulted in an extremely heterogeneous system in which perched water tables and a high 
degree of aquifer partitioning are prevalent in aquifer system. Future studies should focus on delineating this compartmentalization and unraveling geochemical signatures of the fluid system. Coupling of an active hydrologic system with consistent perennial flow and intense recharge / runoff during monsoonal seasons creates a continuously evolving system that can pose significant geohazards as rapid surface denudation continues to breach the system.

\section{References}

Belski D, editor. 1992. GYPKAP report volume \#2. Albuquerque (NM): Southwestern Region of the National Speleological Society.

Eaton J, editor. 1987. GYPKAP 1987 annual report. Alamogordo (NM): Southwestern Region of the National Speleological Society.

Forbes J, Nance R. 1997. Stratigraphy, sedimentology, and structural geology of gypsum caves in east central New Mexico. Carbonates and Evaporites 12 (2): 64-72.

Hill CA. 1996. Geology of the Delaware Basin, Guadalupe, Apache and Glass Mountains: New Mexico and west Texas. Midland (TX): Permian Basin Section of the SEPM.

Hose LD, Pisarowicz JA, editors. 2000. The caves of the Guadalupe Mountains. Journal of Cave and Karst Studies 62 (2).

Kelley VC. 1971. Geology of the Pecos Country, southeastern New Mexico. Socorro (NM): New Mexico Bureau of Mines and Mineral Resources.

Kendall AC, Harwood GM. 1989. Shallow-water gypsum in the Castile Formation - significance and implications. In: Harris PM, Grover GA, editors. Subsurface and outcrop examination of the Capitan shelf margin, northern Delaware Basin. San Antonio (TX): SEPM Core Workshop No 13. p. 451-457.

Kirkland DW, Anderson RY, 1970. Microfolding in the Castile and Todilto evaporites, Texas and New Mexico. Geological Society of America Bulletin 81: 3259-3282.

Kirkland DW, Evans R. 1976. Origin of limestone buttes, Gypsum Plain, Culberson County, Texas. American Association of Petroleum Geologists Bulletin 60: 2005-2018.

Klimchouk A. 2000. Speleogenesis in gypsum. In: Klimchouk A, Ford DC, Palmer AN, Dreybrodt W, editors. Speleogenesis: evolution of karst aquifers. Huntsville (AL): National Speleological Society. p. 261-273.

Klimchouk A. 2007. Hypogene speleogenesis: hydrogeological and morphometric perspective. Carlsbad (NM): National Cave and Karst Research Institute.
Land L. 2006. Hydrogeology of Bottomless Lakes State Park. In: Land L, Lueth V, Raatz B, Boston P, Love D, editors. Caves and karst of southeastern New Mexico. New Mexico Geological Society Guidebook 57. Socorro (NM): New Mexico Geological Society. p. 95-96.

Lee J, editor. 1996. GYPKAP report volume 3. Alamogordo (NM): Southwestern Region of the National Speleological Society.

Lee MK, Williams DD. 2000. Paleohydrology of the Delaware Basin, western Texas: overpressure development, hydrocarbon migration, and ore genesis. Bulletin of the American Association of Petroleum Geologists 84 (7): 961-974.

Nance R. 1993. Application of the standard tablet method to a study of denudation in gypsum karst, Chosa Draw, southeastern New Mexico [MS Thesis]. Greely (CO): University of Northern Colorado. $82 \mathrm{p}$.

Sares SW. 1984. Hydrologic and geomorphic development of a low relief evaporite karst drainage basin, southeastern New Mexico [MS Thesis]. Albuquerque (NM): University of New Mexico. 123 p.

Shaw MG, Stafford KW, Tate BP. 2011. Surface denudation of the Gypsum Plain, west Texas and southeastern New Mexico. U.S. Geological Survey Scientific Investigations Report 2011-5031. Reston (VA): US Geological Survey. p. 104-112.

Scholle PA, Goldstein RH, Ulmer-Scholle DS. 2004. Classic upper Paleozoic reefs and bioherms of west Texas and New Mexico. Socorro (NM): New Mexico Institute of Mining and Technology.

Stafford KW, Nance RG. 2009. Ascending water of the Delaware Basin, southeastern New Mexico and far west Texas. In: White WB, editor. Proceedings of the 15th International Congress of Speleology. Huntsville (AL): National Speleological Society. p. 991-997.

Stafford KW, Nance R, Rosales-Lagarde L, Boston PJ. 2008a. Epigene and hypogene karst manifestations of the Castile Formation: Eddy County, New Mexico and Culberson County, Texas, USA. International Journal of Speleology 37 (2): 83-98.

Stafford KW, Rosales-Lagarde L, Boston PJ. 2008b. Castile evaporite karst potential map of the Gypsum Plain, Eddy County, New Mexico and Culberson County, Texas: A GIS methodological comparison. Journal of Cave and Karst Studies 70 (1): 35-46.

Stafford KW, Ulmer-Scholle D, Rosales-Lagarde L. 2008c. Hypogene calcitization: evaporite diagenesis in the western Delaware Basin. Carbonate and Evaporites 23 (2): 89-103. 
132 NCKRI SYMPOSIUM 2 I3TH SINKHOLE CONFERENCE 